\title{
People of No Land: A Study of the Hajong Tribe of Changlang District of the Diyun Circle of Arunachal Pradesh (On the basis of IMPRESS- ICSSR Project Work)
}

Dr. Adidur Rahman

\author{
Associate Professor, Department of Political Science, Haji Anfar Ali College, College Road, Doboka Town, Nagaon, Assam 782440, India
}

DOI: $10.36347 /$ sjahss.2020.v08i10.003

| Received: 28.09.2020 | Accepted: 25.10.2020 | Published: 30.10.2020

*Corresponding author: Dr. Adidur Rahman

Abstract

Original Research Article

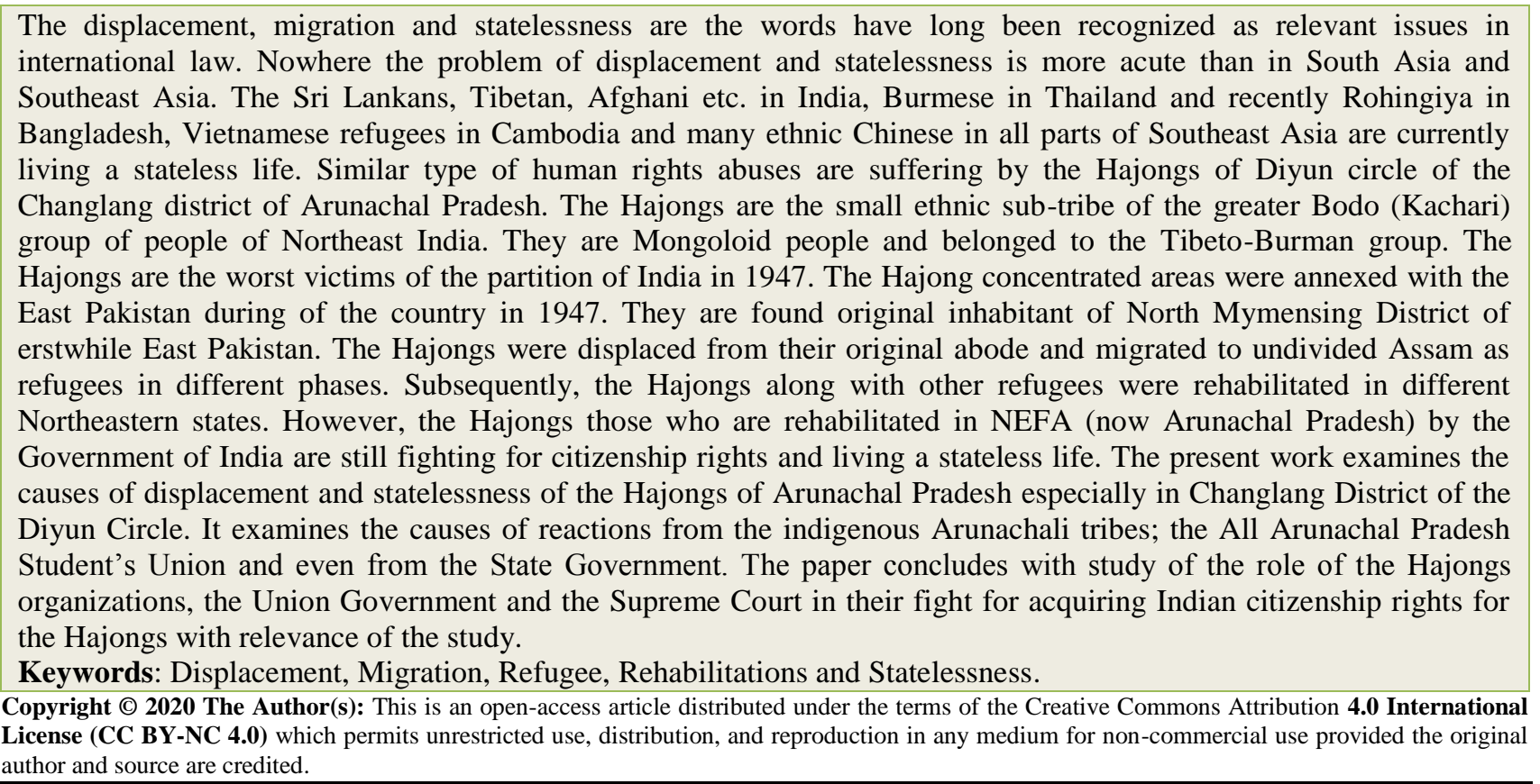

\section{STATEMENT OF THE PROBLEM}

A few words such as displacement, migrations, refugee rehabilitations and statelessness were widely used in international spheres during the World War-II. Since then the displacement of people has been one of the challenge causing statelessness of people in different regions of the world. It obviously renders people homeless and is being deprived of their places of abode. In Indian Sub-Continent several thousand of people have been affected by displacement. During the partition of the country in 1947, the Northeast region of India is territorially organized in such a manner that ethnic and cultural specificities were ignored during the process of delineation of state boundaries, giving rise to discontentment and assertion of one's identity. The region has experienced massive displacement, migration and refugee problem causing statelessness in the wake of independence including the Hajongs of Diyun circle of the Changlang district of Arunachal Pradesh (A.P). The Hajong tribe who were rehabilitated in the Diyun Circle of Changlang district are still deprived of their basic human rights-the right to citizenship and considered as people of no land.

\section{METHODOLOGY}

The Changlang district is chosen purposively for the study as majority of the Hajongs are found rehabilitated in this district. A multi-method approach is adopted for the study, including historical, descriptive. Relevant data are collected from both primary as well as secondary sources. The primary sources include the firsthand information from the informants belonging 
Hajong of Diyun circle. The respondents were selected primarily from the person having good knowledge about the Hajong history, polity and culture. The secondary sources such as relevant books, journals, periodicals and websites have also been consulted in the study.

Aims of the Study: The study is conducted to meet the following objectives:

a) To identify the major causes of displacement, migration and rehabilitation of the Hajongs in the Diyun Circle.

b) To examine the causes of opposition by the indigenous Arunachali tribes of the rehabilitated Hajongs.

c) To study role of the Hajongs organizations and Union Government to resolve the Hajong citizenship issue.

\section{Changlang District: A Brief Profile}

According to a legend prevalent among the local tribes of Diyun that the name Changlang owes its origin to the local indigenous word 'Changlangkan' which means a hilltop where people where people discovered the poisonous herb, as used for poisoning river water for trapping fish. The present Changlang district came into existence through a gradual development of administration. Earlier it was a part of
Tirap district and bifurcated by the A.P. Reorganization of district Amendment Bill, 1987. The Government of A.P. formally declared Changlang as the $10^{\text {th }}$ district on $14^{\text {th }}$ November, 1987. The district lies in the Southeastern corner of A.P. with an area of $4662 \mathrm{sq} . \mathrm{km}$ and lies in between $260^{\circ} 40^{\prime} \mathrm{N}-27040^{\prime} \mathrm{N}$ latitude and $95^{\circ} 1^{,} \mathrm{E}_{-} 97^{0} 1^{, \mathrm{E}}$ longitudes in the globe. The district is bounded by Tinsukia district of Assam and Lohit district of A.P. in the North; Tirap district in the West and by Myanmar in the South-East.

During field survey it is revealed that that the highest numbers of Hajongs refugees are rehabilitated in Diyun Circle of Changlang district. To facilitate the administration, the entire circle is further divided into 31 revenue villages. The Diyun Circle is the most populous Revenue Circle in the Changlang dstrict. As per the latest Census Report (2011), it has population of 32,007 . Out of which 16,227 are male while 15,730 are females. The average sex ratio of Diyun circle is 966 and a total of 5,949 families have been residing in the Circle. However, the population of Diyun Circle has increased by 10.7 per cent in last 10 years. As per the Census Report of 2001, the total population was about 29,000 in comparison to the 32,007 of 2011 . The Castewise male and female population as per 2011 Census Report may be presented in the following char.

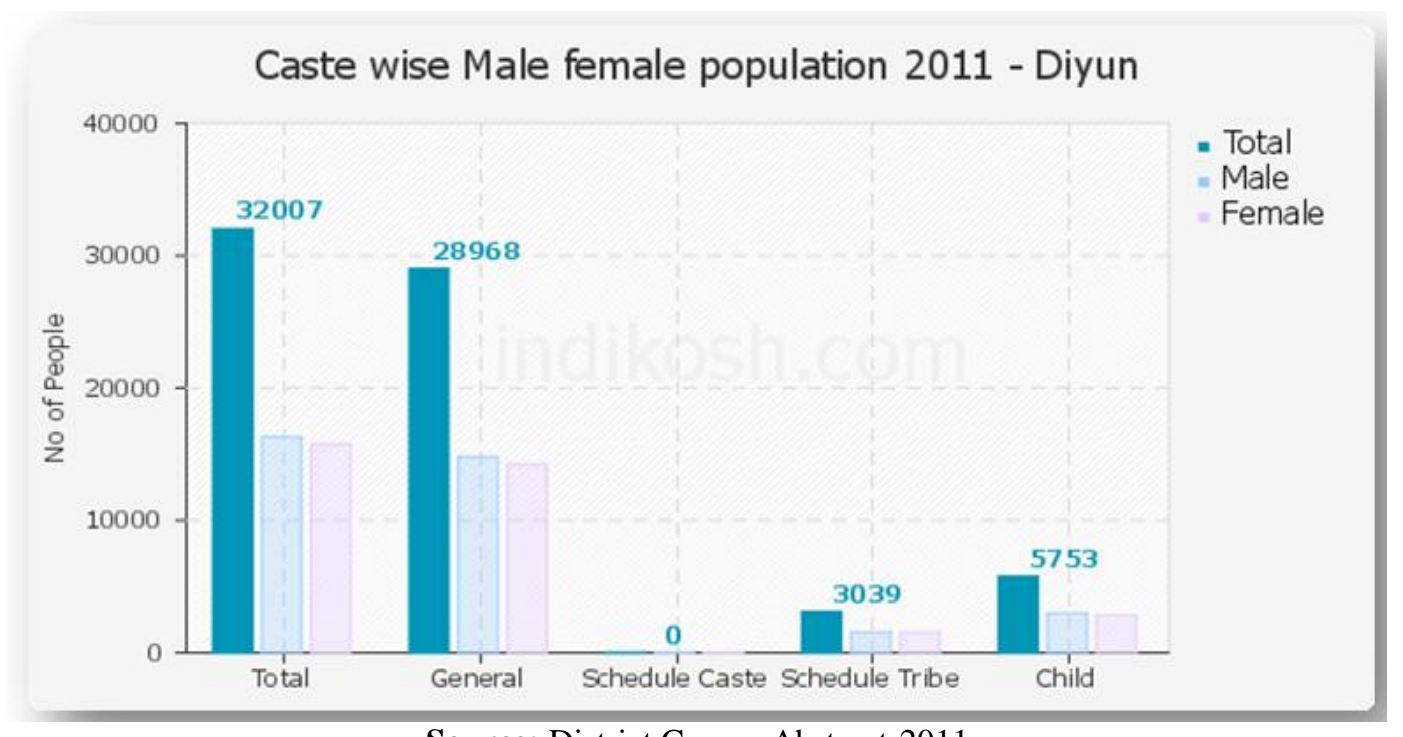

Source: District Census Abstract-2011

\section{Displacement and Migration of Hajongs}

Unlike many other tribes, the history of the Hajongs is a record of distant migration. The word 'migration' has almost become synonymous with the Hajongs. The Hajongs belong to a tribal group which has for centuries inhabited the North of Mymensing District of Bangladesh (earlier East-Pakistan). Since the beginning of the $19^{\text {th }}$ century following natural calamities and socio-political disturbances the Hajongs were disintegrated and displaced from their original abode and started living a scattered refugee life in different parts of undivided Assam in India. After the partition, the Hajongs which remained in East Pakistan (present Bangladesh) was displaced massively. The displacement was caused primarily due to their demand to the Boundary Commission for amalgamation of 'Partially Excluded Areas' of the North Mymensing District with the Indian Union in 1947. The decision of the Boundary Commission was against the Hajongs which annexed the entire inhabitated areas with East Pakistan $\left[{ }^{i}\right]$. The fate of Hajong tribe and other tribes of that area was sealed for good into an abysmal. 
During interview with respondents in Diyun Circle, a number of causes like- demand for separate state known as 'Adhistan' by the Hajongs, Garos and other smaller tribes of the 'Partially Excluded Areas' of East-Bengal [ii], abolition of pre-colonial special status, arrival of Bihari Muslims (Muhazirs) from Bihar to the Hajong inhabitated areas, religious discrimination, and impact of Communist Movement are also found mainly responsible for the displacement and migration of the Hajongs including those who were rehabilitated in the Diyun Circle of Changlang district. Finding no shelter, the Hajongs had left East Pakistan and sought asylum in India as refugee. In 1964, about 15,000 Hajongs refugees migrated to India. M. Hajongs, an inhabitant of Kalmakanda of erstwhile East-Pakistan, presently living in Madhupur, Diyun, A.P., expressed his anguish during interview and said,

"the Hajongs people were worst affected along with other tribes by the bifurcation of the country in 1947. The Hajongs people were mainly concentrated in the Mymensing district of the East Bengal before independence. The freedom fighters had tantalized the Hajongs people. Our forefathers supported the freedom movement in order to free the country from the clutch of the mighty British Raj. The appeal and memorandums submitted by our people to amalgamate our land with the Indian Territory was turned down without assigning any reasons. Even, I remember that some Hajongs people hoisted Indian National flag to celebrate the Independence Day in our locality. But the leaders poured cold water to our long cherished dreams and plunged into grief the whole Hajongs tribe and which helped the anti-people government to displace us forcefully from our land (East Pakistan) [iii].

\section{Rehabilitation in NEFA}

The Hajongs migrated in a hopeless and pathetic condition to of Assam from the erstwhile EastPakistan. According to the Government of India estimate, by the middle of 1964 , at least $1,40,000$ persons including Chakma and Hajongs consisting of 2902 families had migrated to Assam. The then Government of Assam expressed their inability to settle such a large number of migrants in the state and requested for their shifting to other places. It was also suggested that a substantial number of families could be accommodated in NEFA as 'some surplus land was available there in NEFA agreed to accommodate some new migrants including the Hajongs under a 'Definite Plan of Rehabilitation $\left[{ }^{\mathrm{iv}}\right]$ '.

But the rehabilitation of the Hajong and Chakma tribes in NEFA ((now Arunachal Pradesh) become a headache for the administration. It may be mentioned here that the NEFA was administered by the
Ministry of External Affairs of the Government of India with the Governor of Assam acting as an agent to the President of India. On April 10 ${ }^{\text {th }} 1964$, Vishnu Sahay, the Governor of Assam, in his letter No. GA-71/64, dated April 10, $1964\left[^{\mathrm{V}}\right]$, addressed to the then Chief Minister of Assam, Bimala Prasad Chaliha, pointed out that:

"it occurred to me that we may get trouble between the Mizos and the Chakmas in the Mizo district. These Chakmas would be quite suitable people to go into the Tirap Division of NEFA where there is easily found vacant land in the area about which you and I have often spoken $\left[{ }^{\mathrm{vi}}\right]$ "'.

Vishnu Sahay, the Governor of Assam, decided to make necessary arrangement to settle more than 10,000 refugees to Tirap divisions of NEFA to avoid any troubles between local people (Mizos) and refugees. On April 16 ${ }^{\text {th }} 1964$, P.N. Luthara, the advisor to the Governor of Assam, replied that 3000 families of refugees may be rehabilitated and expressed his inability to accommodate 10,000 families. In the mean time there was strong opposition from the indigenous Arunachali tribes against the rehabilitation plans in their areas. In April, 1966, Deputy Secretary (P\&D) Shillong, wrote to the Liaison Officer, Ministry of Labour, Employment and Rehabilitation, NEFA, that:

"in Lohit district we had contemplated to settle 1000 families but on account of opposition from Khamtis, Singhpos, and Mishimis, we had to slow down our program. We shall be rehabilitating nearly 2253 families by the end of 1966-67 [ ${ }^{\mathrm{vii}}$ ]".

In the midst of strong opposition, initially about 57 families of hajong and Chakmas from Ledo Camp of Dibrugarah were settled in Abhaypur block of Diyun Circle of the erstwhile Tirap district of NEFA. The Government records of A.P. indicate that between 1964 and 1969, a total of 2,748 refugees comprising some 14,888 persons were sent to the NEFA. Nearly 1000 members of the Hajong tribe, a Hindu group from Mymensing district of Bangladesh were also settled in these areas [ ${ }^{\text {viii }}$. Initially these refugees were settled in 10,799 acres of land in the three districts namely, Lohit (214 families settled and 1192 persons altogether), Subansiri (now in Papum Pare;238 families and 1133 persons in total) and Tirap (now in Changlang :2146 Chakma families with 11,813 persons in total and 150 Hajong families with 750 persons in total ). By 1979 these figures increased up to 3919 families consisting of 21,494 persons and 65,000 as per census in 1991 [ $\left.^{\mathrm{ix}}\right]$. In 2001 , it has been found that there are more than 85,000 Chakmas and Hajong refugees living in different areas of A.P. especially in Diyun circle of Changlang district. The following table (1) is the indicative of the population growth in Changlang district between 1961 and 1971 as: 
Table-1: Population Growth in Changlang District, 1961-71

\begin{tabular}{|c|l|c|c|l|l|l|}
\hline \multirow{2}{*}{ Year } & \multicolumn{3}{|l|}{ Total Population } & \multicolumn{3}{l|}{ Tribal Population } \\
\cline { 2 - 7 } & Male & Female & Total & Male & Female & Total \\
\hline 1961 & 30,601 & 28,990 & 59,591 & 27,423 & 27,681 & 55,104 \\
1971 & 51,774 & 45,696 & 97,470 & 34,493 & 34,352 & 68,845 \\
\hline
\end{tabular}

Source: Dutta, Choudhury, S. (ed.) 1980. Gazetteer of India, Arunachal Pradesh, Tirap District, Directorate of Information and Public Relations, Shillong, p.43.

\section{Rehabilitation and its Reactions}

The issues of rehabilitation of the Hajong and Chakma refugees have been a matter of simmering discontent among the indigenous tribal people of A.P. There was strong opposition from the indigenous tribes against the Central Government's initiatives of the rehabilitation plans of Hajong and Chakma refugees in their areas. It has been alleged by the local Arunachali tribes that the large influx of the Hajongs and Chakmas from East-Pakistan (now Bangladesh) are responsible for major demographic imbalance and displacement of the indigenous population. The immediate consequence is that the problem of indigenous people getting marginalized and displaced. Apart from the psychological fear of being reduced to a minority in their own habitat, the local Arunachali tribes are afraid of losing control over their ancestral land.

In the wake of anti-foreigners agitation in Assam, the state Government of A.P. undertook a series of repressive measures against the Hajongs and Chakmas beginning in 1980. The All Arunachal Pradesh Students Union (AAPSU) launched 'Refugee go back' movement serving 'Quit Arunachal Pradesh' notice to the settlers to leave the state by 30 September, 1995 , in the wake of 'people's referendum rally 'held on September 20,1995 at Naharlugun, Itanagar $\left[{ }^{\mathrm{x}}\right]$. All the major political parties including the ruling Congress-I Chief Minister Gegong Apang participated at the rally and vowed to resign from the primary membership of parties and organisations if their demand was not met by the Central government before the expiry of the deadline. As a consequence, a large of Hajong and Chakma refugees fled from A.P. and took shelter as refugees in the neighbouring state of Assam. The reality is that the Hajong and Chakmas are at risk of displacement for the second time who is regularly threatened with expulsion by influential Arunachal student's organizations. Even before that state government of A.P. undertook a series of repressive measure including social and economic boycott in support of the agitation programme against the Hajongs. For instance, the Arunachal Government vides its letter No. POL-21/80 dated $29^{\text {th }}$ September 1980, banned public employment for the Hajongs in the state. In 1994, the state government further directed 'withdrawal of all kinds of facilities 'from Hajongs and Chakma settlement areas $\left[{ }^{\mathrm{xi}}\right]$ ' afflicting gross human rights violations of the Hajong refugees.

The state Government of A.P. is of the view that even if the Central Government is obliged to confer citizenship on to the Hajong and Chakma refugees under Indira-Mujib Agreement in 1972 cannot settle them permanently within the state since '.....the Agreement [does] not take away the rights of the state Governments to restrict the entry of non-locals through the instrument of Inner Line Permit (ILP) and not to allow permanent settlements of non-locals in the state. The issue is not of conferment of citizenship rights on these refugees but against the permanent settlement of these refugees in A.P. Furthermore, while responding to the charge of violating the political sanctity of the Indira-Mujib Agreement of 1972 by demanding the removal of the Hajong and Chakma refugees from the state, Ex-Chief Minister of A.P. Mr. G. Apang has remarked:

"The Indira-Mujib accord was signed in 1972; our constitution came into being in 1950. The Indira-Mujib Accord has not mentioned specifically about Chakma and Hajong refugees of Arunachal Pradesh. Moreover, the Chakma and Hajong settlement in the state has been done violating the legal sanctity and constitutional provisions, the questions of violating the political sanctity of Indira-Mujib Accord does not arise [ $\left.{ }^{\mathrm{xi}}\right]$ ".

In fact, the ignorance of the Supreme Court's judgment and callus attitude of the state government and dubious role played by the AAPSU made the Hajong and Chakma refugee issue a more vexed politicized problem in the state. P. Hajong [xiii], a resident of Madhupur-I, Diyun, Changlang of A.P. stated that,

"...the present state of statelessness indicates a close link between the failures of the Central Government in extending the protections of Indian citizenship to the Hajongs on the one hand and their consequent statelessness and human rights violation at the hands of the state government and AAPSU, on the other".

The study reveals that the present condition of statelessness of the Hajong along with Chakmas has made them more susceptible to oppression at the hands of the state Government and the local Arunachali tribes, basically threatening from the AAPSU for mass eviction.

\section{Role of the Central Government}

The Central Government often asserted that the Hajong and Chakmas have a legitimate claim to India citizenship. The desire of granting citizenship to 
the Hajong and Chakma in A.P. by the Centre turned the relationship bitter with the state. Since their resettlement in NEFA during 1964-69, the issue of granting citizenship to the Hajong and Chakma refugees had figured prominently in almost all the debates and was being considered seriously by the Central Government. It becomes clear from the Ex-Home Minister Mr. S. V. Chavan's repeated remarks in this respect met with strong opposition from all quarters in the state. The AAPSU strongly condemned Chavan's initiative on granting citizenship to the Hajong and Chakma refugees and accused that it was an attempt to woo the voters at the cost of annoying the indigenous people of the state. It was only on 23 September 1992 that the first official pronouncement to this effect was made in the Lok Sobha by M. M. Jacob, the Minister of State for Home and Parliamentary Affairs. He categorically stated that being 'New Migrants', viz., refugees from Bangladesh who came to India between 1964 and 1971 respectively, are eligible to the grant of citizenship according to the policy of the Government on the subject and most of these migrants have already been granted citizenship. In fact, the Central Government is strongly of the opinion that citizenship should be granted to the Hajong and Chakma refugees to which they are entitled under the Citizenship Act, 1955, under section 5(1)(a), also reveals the Centre's firm determination to settle them permanently in A.P. This strong perception of the Central Government on the question of Hajong and Chakma citizenship issue was vindicated by the Supreme Court in its historic verdict delivered on 9 January 1996 [xiv].

\section{Fighting for Citizenship Status}

On September 9, 1994, the People's Union for Civil Liberties, Delhi brought the issue of Hajong and Chakmas to the notice of the National Human Rights Commission $\left[{ }^{\mathrm{xv}}\right]$, which in reply issued letters to the Chief Secretary, A.P. and Home Secretary, Government of India for making inquiries in this regard. On October 15, 1994, the Committee for Chakma-Hajong Citizenship Rights filed a representation to NHRC, complaining prosecution of Chakma-Hajong refugees and the later brought the matter before the apex court. The Supreme Court in its historic judgment in January, 1996, in the case of National Human Rights Commission vs. State of Arunachal Pradesh directed the state government to provide adequate protection to the refugees to ensure against their forcible eviction $\left[{ }^{\mathrm{xvi}}\right]$.
Following the Supreme Court directions the Election Commission of India (ECI) after scrutinizing 15,000 applications merely 1,497 Hajong and Chakma tribes born in India between 1964 and 1987 were included in the Voters' List and allowed to exercise their franchise during the 2004 Lok Sabha election. For the first time in the history of their settlement in Arunachal Pradesh, a limited number of Hajong and Chakma were given voting rights as Indian citizens. However, there was vehement protest against the order of the ECI in the state. The AAPSU submitted a memorandum to the ECI demanding revocation of the said order and decided to ban forthcoming Parliamentary Election on 5 May 2004. Even the ExChief Minister Mr. G. Apang resigned from the AllParty Core Committee on the Hajong and Chakma refugee issue in protest against the inclusion of these voters in the electoral rolls. In the midst of severe protest, the ECI held that the non-inclusion of the 1497 voters implied a violation of the constitutional mandate given to it by Article 325.The state government, however, yet to take decision on rest of the Hajong and Chakma refugees seeking Indian citizenship and whose number is growing day by day.

The Hajong continues to face an uncertain future with a status worse than that of refugees-as a stateless people. The denial of right to nationality directly affects their personal security and makes them extremely vulnerable. The lack of citizenship and statelessness deprives them of their basic human rights such as the right to education, health, water, employment, freedom of movement and developmental facilities. This becomes vivid from the expression of 59-year-old villager R. Hajong of Haripur-I, Diyun Circle, Changlang, stated that:

"...I was just fifteen years old when I came to India alonwwith my parents and other neighbours of Nolitabari of erstwhile EastPakistan. I have spent more than half of my life at Diyun, but I am still deprived of my voting rights. Because $i$ am not a citizen of India $\left[{ }^{\mathrm{xvii}}\right]$ ".

The deprivation of political rights of the Chakmas along with Hajongs becomes obvious from the following Table- 2 .

Table-2: Political Conditions of the Chakmas and Hajongs of Arunachal Pradesh

\begin{tabular}{|l|l|}
\hline Political Status & Total Percentage \\
\hline Having Right to Vote & $10 \%$ \\
\hline Not Having Right to Vote/Rejected & $30+40=70 \%$ \\
\hline Minor & $20 \%$ \\
\hline Citizenship Rights & $0 \%$ \\
\hline
\end{tabular}

Source: Prasad. C 2013, India's refugee Regime and resettlement Policy: Chakmas and the Policy of nationality in Arunachal Pradesh, Kalpaz Publication, Delhi, pp.106-107. 
The ignorance of the Supreme Court's judgment, indifferent attitude of the state government and dubious role played by the AAPSU made the Hajong refugee problem a mere politicized issue in recent time. The perception of the respondents of Hajong of Diyun circle becomes evident from the following Table-3:

Table-3: Hurdles on the way of Citizenship Rights of the Hajong
\begin{tabular}{|l|l|l|}
\hline & Respondents & Percentage \\
\hline The Govt. of India & 47 & $13.82 \%$ \\
\hline The State Govt. of A.P. & 80 & $23.52 \%$ \\
\hline AAPSU & 123 & $36.17 \%$ \\
\hline The Local Arunachali Tribes & 90 & $26.47 \%$ \\
\hline
\end{tabular}

Source: Field data generated by the investigator

The above Table-3 indicates that majority of the respondents consider AAPSU is the major hurdle in obtaining citizenship rights for Hajong in A.P. In the absence of any explicit refugee statute, it is not clear as to what shall be the legal status of refugees and how refugee problem shall be handled in India. At present, we have a few laws to tackle refugee problems in India such as the Registration of Foreigners Act, 1939, the Foreigners Act 1946, the Foreigners Order 1948, the Passport Act 1967, the Emigration Act 1983 and above all the Indian Constitution under Art. 21. These are the primary documents dealing with the treatment of foreigners in India. However, the Foreigners Act 1946 prevails over the other Acts. The most significant lacuna in the Act is that it does not comprise the term 'refugee'. Instead the term 'foreigner' was used to cover aliens temporarily or permanently residing in the country. In fact, Indian Government has dealt with refugee issues of different groups with a different administrative approach. According to an eminent legal expert Rajeev Dhavan, "Indian governance has not devised any systemic policy to deal with refugees, but has dealt with each particular crisis differently". As a result the present statelessness issue of Hajong remained an unsolved problem in the state of A.P.

\section{Recent Development}

In its election manifesto for the Lok Sabha elections 2019, the BJP led NDA Government had declared India as 'a natural home for persecuted Hindus'. The NDA government has taken several steps to simplify the process for granting long-term visa and citizenship to Hindu minorities from neighbouring countries. It is worth to mention here that in 2015, the Centre was given a deadline by the Supreme Court to confer citizenship to the Hajong and Chakma refugees within three months. The Arunachal Government approached the apex court and appealed against the order but in vain.

In fact, the initiative on the Chakma and Hajong refugees comes amid the ongoing row over the Central government's plans to deport Rohingya Muslims, who came to India due to alleged persecution in Myanmar. Minister of State for Home Kiren Rijiju, who hails from A. P., had recently raised the citizenship issue at a Northeast meet chaired by Union Home
Minister Rajnath Singh and attended by A. P. Chief Minister P. Khandu, Rijiju and National Security Adviser Ajit Doval. After the hour-long meeting, Rijiju stated that a 'middle ground' will be found so that the 2015 Supreme Court order to grant citizenship to Chakma-Hajong refugees can be honoured and the rights of the local population are not diluted. It becomes obvious that the Centre is trying to find a workable solution by proposing that the refugees will not be given rights, including land ownership, enjoyed by Scheduled Tribes in A. P, an official said. However, they may be given Inner Line Permits (ILP)-required by non-locals in A. P. to travel and work.

Once again, several organisations and civil society outfits in Arunachal have been opposing citizenship to the Chakma and Hajong refugees. They contend that it would change the demography of the state. There was demonstrations and protest by the student's organisations against the move of the Central Government. Rijiju replied that "We are trying to find a middle ground so that the Supreme Court order is honoured, the local people's rights are not infringed, and human rights of the Chakmas and Hajongs are protected." Rijiju further added that a petition may be filed on the issue in Supreme Court soon.

In fact, the passing of CAA (2019) in the Parliament provided a ray of hope to the Hajongs of Diyun of acquiring citizenship status in the state as revealed by many Hajongs during interview with them. However, they also expressed their apprehension that the local indigenous tribes will oppose any move to grant them citizenship status as they did since their rehabilitation. It is also found that the Hajong community people possessing citizenship right was out listed during NRC up gradation in the neighbouring state of Assam in 1918-19.

\section{Relevance of the Study}

The present study on the citizenship rights question and statelessness of the Hajongs especially of Diyun Circle of Changlang District of A.P. have more national as well as international relevance in the present context:

1. The work identifies a number of factors that were mainly responsible for the displacement and 
persecution of the Hajongs from the erstwhile East-Pakistan with the help of available materials.

2. The study tries to focus on the stateless refugee life of the Hajongs of Diyun circle of Changlang District and the role played by the Central Government, State Government, National Human Rights Commissions and even the Supreme Court of India in handling the issue of statelessness of Hajongs in A.P. This is the most relevant point of the study.

3. The study emphasizes that India needs specific refugee laws and policy to tackle massive refugee problem of the country including the Hajongs which is still absent. The massive refugees are treated by some domestic laws of the country which are not enough to resolve the massive refugee issue of the country.

4. During my field study, it is revealed that living a refugee life for a long period, the traditions and identity of the Hajongs are on the verge of ruin. Like many other little known tribes the Hajongs are marginalized. The tribe is affected by poverty, illiteracy and political identity crisis. The study also tries to bring out that the tribe is neither represented politically to the State Assemblies nor any local body in the state of Arunachal Pradesh. It is because of their disintegration and scant in numbers in the state.

5. It tries to draw the attention of the Government as well as the society for the eradication of their deprivation, exploitation, poverty, statelessness of the ethnic group, resolving the inter-ethnic conflict and to bring Hajongs into the mainstream.

6. The study will encourage further investigation and research about other little known tribes like Hajongs refugees in the region who are on the verge of ruin.

\section{CONCLUSION}

There can be no doubt that the Hajongs migrated from the erstwhile East-Pakistan mainly hilly regions of Mymensing district and has been residing in A.P. for more than 50 years. Under the Indira- Mujib Agreement of 1972, it was determined that India and not Bangladesh would be responsible for all migrants who entered India before $25^{\text {th }}$ March 1971. If the Tibetans who fled to A.P. in 1959 can be given Indian citizenship status, why can not the Hajongs, who were given valid migration Certificate and rehabilitated by the Central Government in A.P. This is discrimination towards Hajongs and violations of International Conventions relating to the rights of refugees. More importantly, the state governments of A.P. and the Central Governments in the affidavit to the Delhi High Court have recognized that the Hajongs are indigenous like the rest of the people of A.P. Therefore, it is legitimate on the part of the Hajongs to claim Indian citizenship removing their statelessness in A.P. Simultaneously, basic human rights of indigenous Arunachali tribals need to be protected and both the
Central and State Government should come forward to fulfill their democratic obligations in this regard.

Acknowledgment: MHRD/IMPRESS-ICSSR Research Project Work.

\section{FOOTNOTES}

1. Seikh EA. Hajong Jonoghosti: A Micro-Ethnic Tribe of Northeast India, Bhawani Offset \& Imaging System Pvt. Ltd. Guwahati, 2012; 266.

2. Ibid, p.259.

3. Interviewee: M. Hajongs (78), Madhupur, Diyun circle, A.P.

4. Prasad C. Chakma-Hajong Refugees and Their Rights [Internet]. Global Politician. 2007. Available from:< http://globalpolitician.com/226.>, [Accessed 24 September, 2019].

5. Sing DK. Stateless in South Asia,: The Chakmas between Bangladesh and India, Sage Publication, New Delhi, 2010; 84.

6. White Paper. Government of Arunachal Pradesh, Itanagar. 1996; 9.

7. Letter of the Deputy Secretary (P\&D), Shillong to the Liaison Officer, Ministry of Labour, Employment and Rehabilitation, NEFA, April, 1966.

8. Prasad CN. Students Movements in Arunachal Pradesh and the Chakma-Hajong Refugee problem. 2006. Available from: <http://www.academia.edu> [Accessed on 4 March. 2020]

9. Panigrahi PK. Displacement and Refugee issues in Arunachal Pradesh. In Das SK. (Ed) Blister on their Feet: Tales of Internally Displaced persons in India's North-East, Sage publication, Delhi. 2008; 57.

10. Ray Chaudhary AB, Das Samir K. A Report on: The Stateless Chakmas in Arunachal Pradesh, Mahanirban, Research Group, Calcutta. 2011; 33.

11. Ibid,.p.33.

12. Sing DK. op. cit., p. 145.

13. Interviewee: P. Hajong (47), Madhupur-I, Diyun circle, Changlang, A.P.

14. Sing DK. Stateless in South Asia, The Chakmas between Bangladesh and India, Sage Publication, New Delhi, 2010; 135.

15. Agarwal HO. Human Rights, Central Law Pub, Dharbhanga Castle, Allahabad, U.P. 2008; 306.

16. Zutshi RT, Satpute J, Tahir S. (ed.). Refugees and the Laws, Human Rights Law Network (HRLN) Publisher, New Delhi-110014, 2011; 107.

17. Interviewee: R Hajong (59) Haripur-1, Diyun circle, A.P. 